\title{
Assessing the Strength of Lightweight Concrete using Oil Palm Shells (OPS) as Coarse Aggregates
}

\author{
Adamtey Simon Asinor ${ }^{1}$, Ofosu Samuel Anim ${ }^{2}$ \\ ${ }^{1}$ Building Technology, Koforidua Polytechnic, P. O. Box KF 981, Koforidua, Ghana \\ Email:bbosqo@yahoo.com \\ ${ }^{2}$ Civil Engineering Department, Koforidua Polytechnic, P. O. Box KF 981, Koforidua, Ghana \\ Email:sambrianogh@hotmail.co.uk
}

\begin{abstract}
The usage of concrete spans the length of civilization and in modern day construction environment, concrete remains one of its major materials. As a result of high cost of construction and construction materials especially in Ghana and other developing countries in West Africa, different efforts have been made to find alternative local building materials to substitute wholly or partly some of the constituents of concrete. This paper looks at the potential of oil palm shells (OPS) as coarse aggregate in lightweight concrete by mainly assessing the compressive strength of OPS concrete and also establish the best mix ratio for OPS concrete. The coarse aggregate of the mix ratios 1:2:4 and 1:3:6 were replaced with OPS and their densities and compressive strengths determined on the $7^{\text {th }}$, $21^{\text {st }}$ and $28^{\text {th }}$ days of the concrete maturity. It was found that OPS can be used to replace coarse aggregate up to $75 \%$ in 1:2:4 mix ratio and up to $50 \%$ in 1:3:6 mix ratio. It is therefore recommended that the best mix ratios are 1:2:2:2 and 1:3:3:3. Single storey residential buildings, offices and footbridges are some of the recommended structures that OPS concrete could be suitable for.
\end{abstract}

Keywords: Lightweight concrete; oil palm shell aggregates; density; concrete cubes; concrete maturity

\section{Introduction}

Concrete has been the most common building material for many years. It is expected that concrete would remain a building material in the coming decades. Mass concrete dams, reinforced concrete buildings, prestressed concrete bridges and precast concrete components are some typical examples. It is anticipated that the rest of the developing world will use these forms of construction in their future development of infrastructure.

Concrete is a composite material comprising of aggregates, a binder and water. The strength of concrete depends on the proportions of the mix ratio and the water content. The durability of concrete is the ability of the concrete mix to resist detrimental effects from the environment and to perform satisfactorily (in spite of these effects) under service conditions in the duration of its service life (Teo et al, 2008).

The growing concern of resource depletion and global pollution has challenged many engineers and researchers to seek and develop new materials relying on renewable resources. These include the use of byproducts and waste materials in building construction.
Many of these by-products are used as aggregates for the production of lightweight concrete. Although there has been much research conducted on the structural performance of lightweight aggregate concrete, these are mostly naturally occurring aggregates, manufactured aggregates, and aggregates from industrial by-products.

Oil Palm Shell (OPS) is a by-product of the production of palm oil. OPS is treated as waste and normally disposed through incineration or at times left to rot in huge mounds. OPS are hard in nature and do not deteriorate easily once bound in concrete and therefore it does not contaminate or leach to produce toxic substances (Basri et al, 1999). On the contrary to artificially produced aggregates or industrial byproducts, OPS aggregates do not need to be processed; chemical pre-treatment is not required before use. The bulk density of OPS is between $500 \mathrm{~kg} / \mathrm{m}^{3}$ and 600 $\mathrm{kg} / \mathrm{m}^{3}$ which produces lightweight concretes with a density of about $1900 \mathrm{~kg} / \mathrm{m}^{3}$. Experimental results show that OPS concrete easily attains the strength of more than $17 \mathrm{~N} / \mathrm{mm}^{2}$ (Mannan et al, 2004), which is a requirement for structural lightweight concrete as per ASTM C330. 
With the establishment of palm oil producing companies like Benso Oil Palm Company and other small-scale palm kernel oil extracting firms in Ghana and in other countries of West Africa, large amounts of OPS is produced and treated as waste. At mills, where palm oil fresh fruit bunches are processed and oil extracted, solid residues and liquid wastes are generated. These by-products include empty fruit bunches, fibres, shells, and effluents which are mostly thrown away as solid waste or burnt in support to firewood for traditional local domestic use.

Exploiting this waste material not only maximises the use of oil palm but also helps preserve natural resources and maintain ecological balance. OPS is also cheap and easily available. Currently, there is an increased demand for low-cost housing in Ghana and OPS can be used as an alternative to the conventional and traditional costly natural gravel as coarse aggregates in fulfilling this demand.

\section{Research methodology}

A reconnaissance survey was done at areas relevant to the research. Literature relating to the research was reviewed and works done by other researchers were read and evaluated. The literature reviewed also gave the research team some secondary data from experimental results obtained by other authors.

\subsection{Sourcing of materials}

The OPS aggregates were obtained from local oil palm mills. One is located at Ada, along the KoforiduaNkurakan road and another is located at New Tafo in the East-Akim Municipality. The river sand, Ordinary Portland Cement and the granite coarse aggregates were obtained from local suppliers. Sieve analysis was performed on the OPS and the granite to determine the particle size distribution.

\subsection{Sieve analysis}

The sieve analysis was based on ASTM C - 330 and the results for the tests are given in Table 1. Granite material of dry mass $1000 \mathrm{~g}$ was sampled for the analysis.

OPS material of mass $300 \mathrm{~g}$ was sampled and the results are shown in Table 2. The graph of the sieve analysis is shown in Figure 1.

Table 1

Results of sieve analysis for coarse aggregates

\begin{tabular}{ccccc}
\hline $\begin{array}{c}\text { Sieve size } \\
(\mathrm{mm})\end{array}$ & Weight Retained $(\mathrm{g})$ & $\begin{array}{c}\text { Percentage Retained } \\
(\%)\end{array}$ & $\begin{array}{c}\text { Cumulative Percentage } \\
\text { Retained }(\%)\end{array}$ & $\begin{array}{c}\text { Cumulative } \\
\text { Percentage Passing } \\
(\%)\end{array}$ \\
\hline 19 & 315 & 31.5 & 31.5 & 68.5 \\
12.7 & 635 & 63.5 & 95 & 5.0 \\
9.53 & 43 & 4.3 & 99.3 & 0.7 \\
6.35 & 3 & 0.3 & 99.6 & 0.4 \\
4.76 & 2 & 0.2 & 99.8 & 0.2 \\
4.75 & 1 & 0.1 & 99.9 & 0.1 \\
\hline
\end{tabular}

Table 2

Results of sieve analysis for OPS

\begin{tabular}{ccccc}
\hline Sieve Size (mm) & Weight Retained (g) & $\begin{array}{c}\text { Percentage } \\
\text { Retained (\%) }\end{array}$ & $\begin{array}{c}\text { Cumulative Percentage Cumulative Percentage } \\
\text { Retained (\%) }\end{array}$ & $\begin{array}{c}\text { Passing (\%) } \\
12.7\end{array}$ \\
9.53 & 75.46 & 5.15 & 5.15 & 94.85 \\
6.35 & 14.53 & 23.51 & 28.66 & 71.34 \\
4.76 & 47.98 & 49.62 & 78.28 & 21.72 \\
4.75 & 16.66 & 15.99 & 94.28 & 5.72 \\
\hline
\end{tabular}




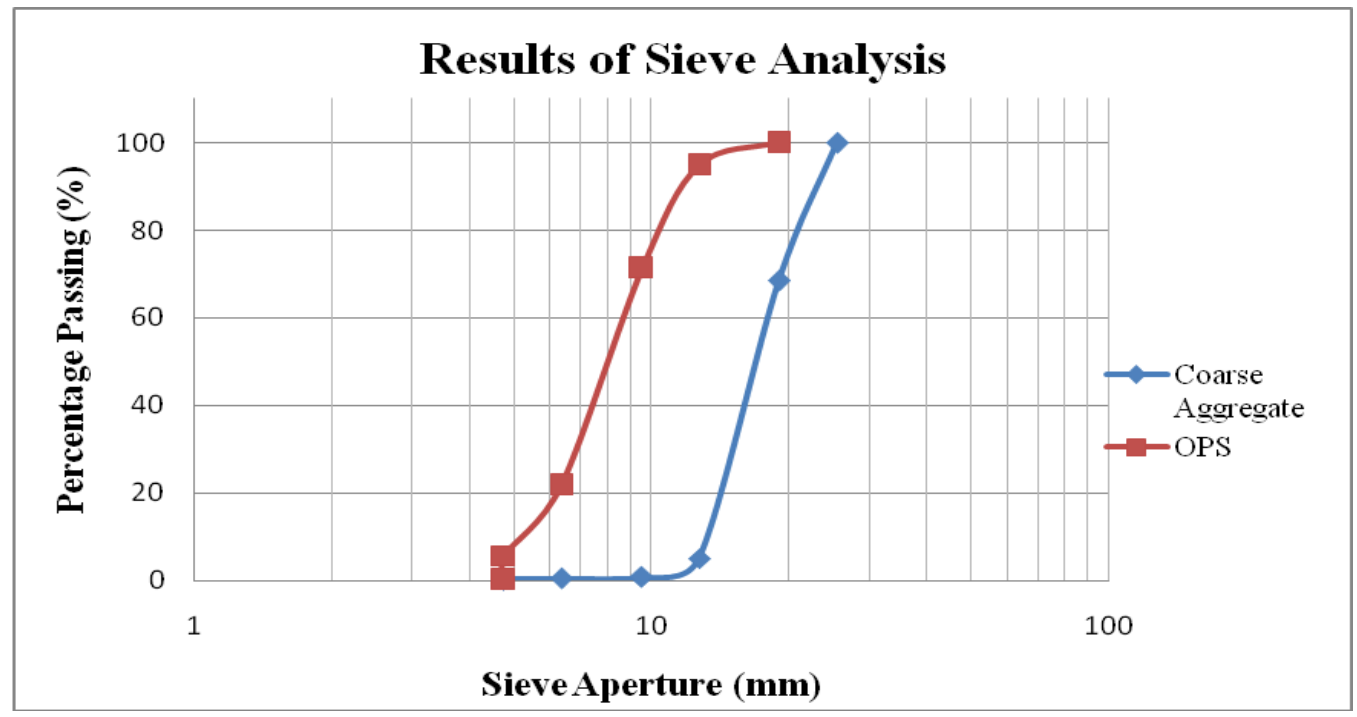

Fig. 1: Graph of sieve analysis

Table 3 shows the comparison between the properties of OPS and granitic aggregates used for the concrete.

Table 3

Comparison of properties of aggregates

\begin{tabular}{clcc}
\hline Serial No. & \multicolumn{1}{c}{ Property } & Coarse Aggregate & OPS \\
\hline 1 & $\begin{array}{l}\text { Maximum Aggregate size } \\
(\mathrm{mm})\end{array}$ & 19 & 12.7 \\
2 & Shell thickness $(\mathrm{mm})$ & - & $0.3-3.5$ \\
3 & Bulk Density $\left(\mathrm{kg} / \mathrm{m}^{3}\right)$ & 1490 & 614 \\
4 & Specific Gravity & 2.67 & 1.24 \\
\hline
\end{tabular}

\subsection{Sampling of materials}

The test concrete cubes were cast, cured under standard conditions and crushed at various concrete ages. The various mix ratios for the experiment are shown in Table 4 and Table 5.

Table 4

Mix ratio for first experiment (1:2:4 variations)

Serial No. Cement $\quad$ Fine Aggregate Coarse Aggregate $\quad$ OPS

\begin{tabular}{lllll}
\hline 1 & 1 & 2 & 4 & 0 \\
2 & 1 & 2 & 3 & 1 \\
3 & 1 & 2 & 2 & 2 \\
4 & 1 & 2 & 1 & 3 \\
5 & 1 & 2 & 0 & 4 \\
\hline
\end{tabular}


Table 5

Mix ratio for second experiment (1:3:6 variations)

\begin{tabular}{ccccc}
\hline Serial No. & Cement & Fine Aggregate & Coarse Aggregate & OPS \\
\hline 1 & 1 & 3 & 6 & 0 \\
2 & 1 & 3 & 5 & 1 \\
3 & 1 & 3 & 4 & 2 \\
4 & 1 & 3 & 3 & 3 \\
5 & 1 & 3 & 2 & 4 \\
6 & 1 & 3 & 1 & 5 \\
7 & 1 & 3 & 0 & 6 \\
\hline
\end{tabular}

The water/cement ratio for the mix was 0.6 and the batching was by weight.

\subsection{Slump test}

The major test that was conducted on the fresh concretes produced was the slump test. The Normal Weight Concrete (NWC) and OPS concrete produced slump values of about $25 \mathrm{~mm}$ and $45 \mathrm{~mm}$ respectively. The slump test was used to test the workability of the mix ratios.

\subsection{Testing of concrete cubes}

Crushing of the concrete cubes was done on the $7^{\text {th }}$, $21^{\text {st }}$ and $28^{\text {th }}$ days of maturity. The cubes were of size $100 \mathrm{~mm}$ square. Three cubes were crushed per day for each mix ratio. This was done to determine the compressive concrete cube strength. The weight and density of the concrete cubes were also determined.

\section{Results and discussions}

\subsection{Results}

The compressive strengths and densities obtained from the tests on 1:2:4 mix ratio variations with OPS are shown in Table 6 and Table 7 respectively.

The concrete compressive strengths of the 1:2:4 variations are shown in Figure 2.

Table 6

Compressive strength of test cubes (1:2:4 variations)

\begin{tabular}{ccccc}
\hline S/N & $\begin{array}{c}\text { Mix } \\
\text { Ratio }\end{array}$ & $\begin{array}{c}\text { Compressive Strength }\left(\mathrm{N} / \mathrm{Mm}^{2}\right) \text { at } 7, \\
\text { 21, 28 Days } \\
\text { 7 Days }\end{array}$ & 21 Days & 28 Days \\
\hline 1 & $1: 2: 4: 0$ & 13.00 & 15.33 & 18.27 \\
2 & $1: 2: 3: 1$ & 8.33 & 10.27 & 13.88 \\
3 & $1: 2: 2: 2$ & 5.67 & 6.88 & 8.15 \\
4 & $1: 2: 1: 3$ & 3.32 & 4.79 & 5.80 \\
5 & $1: 2: 0: 4$ & 1.40 & 2.00 & 2.47 \\
\hline
\end{tabular}

Table 7

Densities of test cubes (1:2:4 variations)

\begin{tabular}{ccccc}
\hline S/N & Mix ratio & \multicolumn{3}{c}{ Density $\left(\mathrm{kg} / \mathrm{m}^{3}\right)$ at $7,21,28$ days } \\
& & 7 Days & 21 Days & 28 Days \\
\hline 1 & $1: 2: 4: 0$ & 2474 & 2433 & 2346.67 \\
2 & $1: 2: 3: 1$ & 2205 & 2264 & 1956 \\
3 & $1: 2: 2: 2$ & 2060 & 1983 & 1851 \\
4 & $1: 2: 1: 3$ & 1351 & 1379.33 & 1451.33 \\
5 & $1: 2: 0: 4$ & 1474 & 1484.67 & 1481 \\
\hline
\end{tabular}

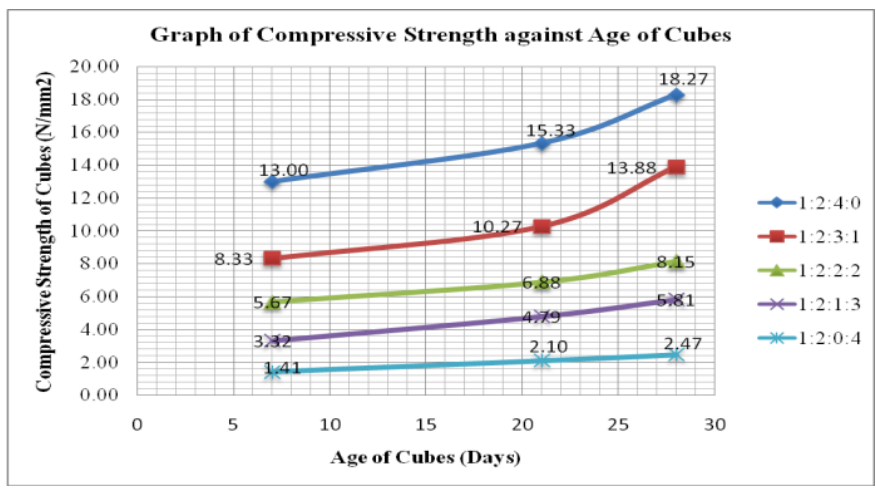

Fig. 2: Compressive strengths (1:2:4 Variations)

The compressive strengths and densities obtained from the tests on 1:3:6 mix ratio variations with OPS are shown in Table 8 and Table 9 respectively.

The concrete compressive strengths of the 1:3:6 variations are shown in Figure 3. 
Table 8

Compressive strengths of test cubes (1:3:6 variations)

\begin{tabular}{ccccc}
\hline S/N & Mix ratio & \multicolumn{3}{c}{ 20mpressive strength $\left(\mathrm{N} / \mathrm{mm}^{2}\right)$ at 7,} \\
& & 7 Days & 21 Days & 28 Days \\
\hline 1 & $1: 3: 6: 0$ & 6.30 & 8.80 & 13.91 \\
2 & $1: 3: 5: 1$ & 4.19 & 6.24 & 9.77 \\
3 & $1: 3: 4: 2$ & 3.20 & 5.23 & 7.30 \\
4 & $1: 3: 3: 3$ & 2.81 & 4.67 & 5.55 \\
5 & $1: 3: 2: 4$ & 0.92 & 1.37 & 2.10 \\
6 & $1: 3: 1: 5$ & 0.44 & 0.78 & 1.22 \\
7 & $1: 3: 0: 6$ & 0.24 & 0.53 & 0.71 \\
\hline
\end{tabular}

Table 9

Densities of test cubes (1:3:6 variations)

\begin{tabular}{ccccc}
\hline \multirow{2}{*}{ S/N } & \multirow{2}{*}{ Mix ratio } & \multicolumn{3}{c}{ Density $\left(\mathrm{Kg} / \mathrm{m}^{3}\right)$ at $7,21,28$ Days } \\
& & 7 Days & 21 Days & 28 Days \\
\hline 1 & $1: 3: 6: 0$ & 2496.00 & 2462.00 & 2412.53 \\
2 & $1: 3: 5: 1$ & 2311.46 & 2262.32 & 2201.10 \\
3 & $1: 3: 4: 2$ & 2156.00 & 1943.00 & 1926.00 \\
4 & $1: 3: 3: 3$ & 1723.14 & 1742.00 & 1717.00 \\
5 & $1: 3: 2: 4$ & 1541.00 & 1416.13 & 1422.00 \\
6 & $1: 3: 1: 5$ & 1367.00 & 1348.00 & 1344.00 \\
7 & $1: 3: 0: 6$ & 1355.00 & 1365.00 & 1343.00 \\
\hline
\end{tabular}

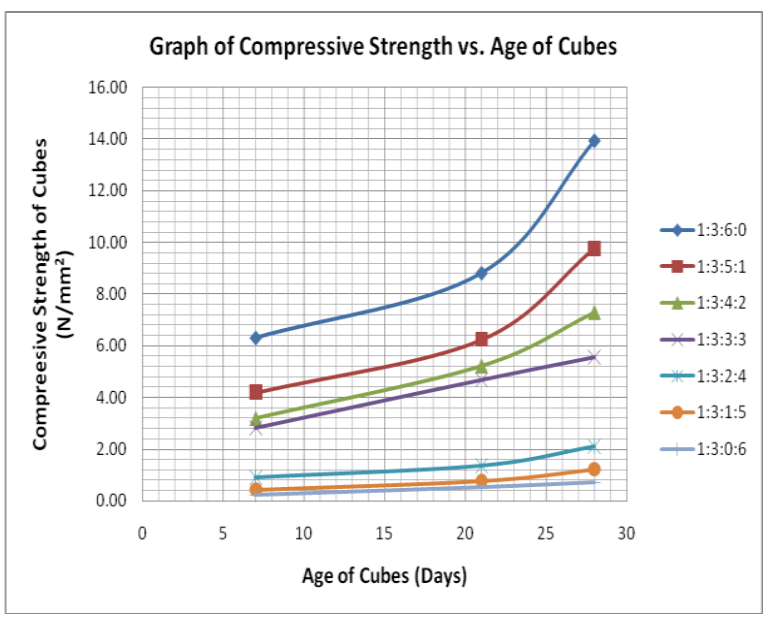

Fig.3: Compressive strengths (1:3:6 Variations)

\subsection{Discussions}

According to Newman (1979), the required density range for a normal dense concrete is $2100 \mathrm{Kg} / \mathrm{m}^{3}$ to $2500 \mathrm{Kg} / \mathrm{m}^{3}$.

The average density for the normal dense concrete $(1: 2: 4)$ is $2346.67 \mathrm{~kg} / \mathrm{m}^{3}$ on the $28^{\text {th }}$ day of maturity and that of 1:3:6 is $2412.53 \mathrm{Kg} / \mathrm{m}^{3}$. These densities fall within the required density range for a normal dense concrete. The concrete compressive strength of C20 is
$20 \mathrm{~N} / \mathrm{mm}^{2}$ and C15 is $15 \mathrm{~N} / \mathrm{mm}^{2}$ (28 days of maturity).Concrete grade $\mathrm{C} 20$ was used for 1:2:4 and grade $\mathrm{C} 15$ was used for 1:3:6. The average concrete cube strengths at 28 days of maturity of the 1:2:4 and 1:3:6 cubes are $18.27 \mathrm{~N} / \mathrm{mm}^{2}$ and $13.91 \mathrm{~N} / \mathrm{mm}^{2}$ respectively.

Lightweight concrete, according to Newman (1979) can be produced with a density range of approximately

$300 \mathrm{~kg} / \mathrm{m}^{3}-2000 \mathrm{~kg} / \mathrm{m}^{3}$, corresponding to concrete cube strengths from approximately $1 \mathrm{~N} / \mathrm{mm}^{2}$ to over $60 \mathrm{~N} / \mathrm{mm}^{2}$. The results above indicate that, the average compressive strength of various mix ratios were within the range required for a normal lightweight concrete.

\subsubsection{Mix ratios and their coarse aggregate percentage reduction}

The main expected output of this investigation includes the best mix ratio for OPS concrete as lightweight concrete. The compressive strengths were obtained using the concrete cube crushing test and relative frequency was used to obtain the percentage reduction of coarse aggregates in the various mix ratios.

\section{A) (1:2:4) Variations}

The percentage reduction of coarse aggregate and the compressive strength of the various mix ratios are as follows:

1:2:3:1- The coarse aggregate percentage reduction is $25 \%$ with a compressive strength of $13.88 \mathrm{~N} / \mathrm{mm}^{2}$.

1:2:2:2 - 50\% reduction in coarse aggregate with $8.15 \mathrm{~N} / \mathrm{mm}^{2}$ compressive strength.

1:2:1:3 - 75\% of the coarse aggregate was replaced with OPS and the compressive strength is $5.80 \mathrm{~N} / \mathrm{mm}^{2}$. 1:2:0:4 - This mix has no coarse aggregate $(100 \%$ OPS) and the compressive strength is $2.47 \mathrm{~N} / \mathrm{mm}^{2}$.

The various mix ratios for the '1:2:4 variations' and their corresponding coarse aggregate percentage reduction have been summarized in Table 10.

Table 10

Percentage reduction of coarse aggregate (1:2:4 variations)

\begin{tabular}{cccc}
\hline S/N & Mix ratio & $\begin{array}{c}\text { Compressive } \\
\text { strength }\end{array}$ & $\begin{array}{c}\text { Percentage } \\
\text { reduction }\end{array}$ \\
\hline $\mathbf{1}$ & $1: 2: 3: 1$ & 13.88 & $25 \%$ \\
$\mathbf{2}$ & $1: 2: 2: 2$ & 8.15 & $50 \%$ \\
$\mathbf{3}$ & $1: 2: 1: 3$ & 5.80 & $75 \%$ \\
$\mathbf{4}$ & $1: 2: 0: 4$ & 2.47 & $100 \%$ \\
\hline
\end{tabular}




\section{A) (1:3:6) Variations}

The percentage reduction of coarse aggregate and the compressive strength of the various mix ratios are as follows:

1:3:5:1 - The coarse aggregate percentage reduction is $16.67 \%$ and the compressive strength is $9.77 \mathrm{~N} / \mathrm{mm}^{2}$.

1:3:4:2 - The coarse aggregate percentage reduction is $33.33 \%$ and the compressive strength is $7.30 \mathrm{~N} / \mathrm{mm}^{2}$.

1:3:3:3 - 50\% of the coarse aggregate was replaced with OPS and the compressive strength is $5.55 \mathrm{~N} / \mathrm{mm}^{2}$. 1:3:2:4 - The coarse aggregate percentage reduction is $66.67 \%$ and the compressive strength is $2.10 \mathrm{~N} / \mathrm{mm}^{2}$.

1:3:1:5 - The coarse aggregate percentage reduction is $83.33 \%$ and the compressive strength is $1.20 \mathrm{~N} / \mathrm{mm}^{2}$.

1:3:0:6 - This mix has no coarse aggregate $(100 \%$ OPS) and the compressive strength is $0.71 \mathrm{~N} / \mathrm{mm}^{2}$.

The various mix ratios for the '1:3:6 variations' and their corresponding coarse aggregate percentage reduction have been summarized in Table 11.

Table 11

Percentage reduction of coarse aggregate (1:3:6 variations)

\begin{tabular}{cccc}
\hline S/N & Mix ratio & $\begin{array}{c}\text { Compressive } \\
\text { strength }\end{array}$ & $\begin{array}{c}\text { Percentage } \\
\text { reduction }\end{array}$ \\
\hline $\mathbf{1}$ & $1: 3: 5: 1$ & 9.77 & $16.67 \%$ \\
$\mathbf{2}$ & $1: 3: 4: 2$ & 7.30 & $33.33 \%$ \\
$\mathbf{3}$ & $1: 3: 3: 3$ & 5.55 & $50 \%$ \\
$\mathbf{4}$ & $1: 3: 2: 4$ & 2.10 & $66.67 \%$ \\
$\mathbf{5}$ & $1: 3: 1: 5$ & 1.22 & $83.33 \%$ \\
$\mathbf{6}$ & $1: 3: 0: 6$ & 0.71 & $100 \%$ \\
\hline
\end{tabular}

\section{Conclusions}

The main objective of this paper was to investigate the various strength characteristics at different material ages of lightweight concrete produced from oil palm shells. From the results obtained, it can be concluded that:

1. The slump values of $25 \mathrm{~mm}$ and $45 \mathrm{~mm}$ for NWC and OPS concrete respectively describe the two mixes as highly workable.

2. Oil Palm Shell can be used to replace coarse aggregate up to $75 \%$ in 1:2:4 mix ratio and up to $50 \%$ in $1: 3: 6$ mix ratio.

3. The best mix ratios are $1: 2: 2: 2$ and $1: 3: 3: 3$ with $8.15 \mathrm{~N} / \mathrm{mm}^{2}$ and $5.55 \mathrm{~N} / \mathrm{mm}^{2}$ compressive strengths respectively.

4. The economic power of the rural dwellers will be enhanced if they are encouraged to plant palm trees from which these shells could be produced.
5. OPS can reduce the cost of concrete and hence developing countries like Ghana can use it in the production of affordable houses.

OPS concrete could be suitable for single storey residential buildings, single storey offices and footbridges.

The specific parts or components of structures that OPS concrete can be used are:

1. General structures: Blinding, Mass concrete, Foundation walls, Basement walls, Partition walls, Reinforced floor slabs, septic tanks and stairways.

2. Agricultural structures: Floors for dairy and beef cattle, pigs and poultry, Floors in grain and potato stores, hay barns, and machinery stores, Slabs for farm yard manure;

3. Civil works: Light traffic roads, driveways, paving and walkways.

Further studies may be conducted on improving the strength of OPS concrete using additives.

\section{Acknowledgment}

The research work was sponsored by Koforidua Polytechnic through the Applied Research Unit.

\section{References}

Basri, H. B., Mannan, M. A. and Zain, M. F. M., (1999). Concrete Using Waste Oil Palm Shells as Aggregate,Cement and Concrete Research, Vol.29, No.4, pp.619-622.

Mannan, M. A. and Ganapathy, C., (2004). Concrete from an Agricultural Waste-Oil Palm Shell (OPS), Building and Environment, Issue 39, No.4, pp. 441448.

Teo, D.C.L., Mannan, M.A. and Kurian, V.J., (2008). "Utilization of Solid Waste Oil Palm Shell (OPS) in Concrete Production", Proceedings of the International Conference on Natural Resources and Environmental Management, Kuching, Sarawak, Malaysia, pp. 135-140, pp.2005.257.

Newman, J.B. (1979).Concrete Under Complex States of Stress.In Lydon, F.D. (ed.)Developments in Concrete Technology-1 Applied Science Publishers, Chapter 5. 